\title{
REVIEW
}

\section{A REVIEW OF THE MAN AND THE BIOSPHERE PROGRAMME IN SRI LANKA}

\author{
M. WATSON \\ National Science Foundation, Maitland Place, Colombo 07.
}

(Received:07 March 1998 ; accepted : 05 May 1998)

\begin{abstract}
This paper summarises the major programmes carried out under the purview of the Man and Biosphere National Committee of Sri Lanka. Uncler the UNESCO MAB programme 41 forest reserves covering a total extent of 72760 ha have been demarcated. Two of these viz, Hurulu and Sinharaja, were admitted to the international network of biosphere reserves. The study of the environmental impacts of the Mahaweli Irrigation Project initiated in 1.977 was a major contribution towards environment conservation and sustainable development. Progress was made on the revision of Trimen's Handbook to the Flora of Ceylon, originally published between 1893 and 1900. The project on the preparation of checklists and handbooks to the fauna and flora, and other activities such as international/regional workshops and future directions of the MAB programme in Sri Lanka are briefly discussed.
\end{abstract}

Key words: Biosphere, conservation, fauna, flora, humid forests, protected area, Sinharaja

\subsection{INTRODUCTION}

The "Man and the Biosphere" programme (MAB) was launched by UNESCO in 1971 as an interdisciplinary and intergovernmental programme. It was a clirect outcome of the UNESCO-Biosphere Conference of 1968 which drew attention to the urgent need for a more rational approach to the use of natural resources. The main objective of the MAB programme was to develop the basis, within the natural and the social sciences, for the conservation and rational use of nature and the resources of the biosphere. The programme in Sri Lanka was coordinated by NARESA* (then the National Science Council, under the Ministry of Scientific Affairs) and the Sri Lanka National Commission for UNESCO (SLNC). A National Committee for the Man and the Biosphere programme was appointed in 1971 by the Minister of Education, under whose purview the SLNC functioned, with the concurrence of the Minister of Industries and Scientific Affairs. The Committee consisted of 12 members drawn from universities, research organisations, and relevant government departments. The National Committee presently functions directly under NARESA in the Ministry of Science \& Technology. It is reconstituted every 2-3 years. By the 1980s several non-governmental organisations (NGOs) had gained acceptance as responsible champions of the cause of environmental conservation. The Ministry recognised the positive role they could play by appointing

\footnotetext{
"In all future references to "NARESA" no distinction is made between NARESA and its predecessor, the National Science Council.
} 
representatives of three NGOs to the MAB Committee in 1992.

The first MAB Committee took note of the very rapid destruction that was going on of the few remaining natural forests in the island and the acute shortage of personnel trained in environmental studies. High priority was therefore given to the establishment and protection of forest reserves and to the education and training of personnel in environmental studies. The Committee identified the following broad areas for study - taxonomy, ecology, a survey of natural resources, and pollution. Subcommittees were appointed where necessary to identify specific project areas and personnel commissioned to carry out the work. With the establishment of a statutory Committee on Natural Resources in 1982, this aspect of the work was transferred to the new Committee. However oversight of the work handled by the National Mangrove Committee, established in 1984, and the Technical Committee for Conservation of Genetic Resources, set up in 1988 was passed on to the MAB Committee with the dissolution of these Committees in 1992.

It is not possible to deal with every aspect of the work undertaken by the MAB Committee over a period of over 25 years, in this paper. Only the most important programmes are discussed under the following subheadings - biosphere reserves, research, education and training in environmental studies, completion of the revision of the Flora of Ceylon, and other activities.

\subsection{BIOSPHERE RESERVES}

Biosphere reserves are "areas of terrestrial and coastal / marine ecosystems or a combination thereof, which are internationally recognised within the framework of UNESCO's Programme on Man and the Biosphere". In 1969 the local Committee of the International Biological Programme demarcated a number of 20 ha blocks of forests as arboreta in the main bio-climatic zones of Sri Lanka. With the IBP projects coming under UNESCO in 1971, and expansion of this programme as the Man and Biosphere Programme, larger forest areas both natural and planted were declared MAB reserves. This was done by the Conservator of Forests on the recommendation of the $\mathrm{MAB}$ Committee. Up to this time, forests were considered primarily as a resource for timber extraction, and the declaration of the national MAB reserves marked a shift in emphasis from timber production to conservation.

At present there are $41 \mathrm{MAB}$ reserves covering a total extent of $72760 \mathrm{ha}$. Two reserves viz, Hurulu and Sinharaja have been admitted to the world network of biosphere reserves with their designation as international MAB reserves in 1977 and 1978 respectively. 
The special features of the international MAB reserves are -

- they form part of an international network

- $\quad$ they provide for manipulative research in portions of the reserves

- $\quad$ they combine conservation, research, education \& training as major objectives

- $\quad$ they play an integrative role with local communities whose social and economic activities comprise a significant management input they focus their efforts on the relationship between man and the biosphere

The world network of biosphere reserves comprises 352 reserves from 87 countries.

Although a progressive transition from the strictly protected area to an area of sustainable use by man for agriculture, settlement or other activities was conceptualised at a very early stage of the biosphere reserve concept, the MAB reserves in the country were totally dedicated for conservation. Thus they correspond to the "core area" set apart for conserving biological diversity, monitoring minimally disturbed ecosystems, and undertaking nondestructive research and other uses such as education. The other two elements of the MAB reserve concept are, the "buffer zone" and the "transition area". The buffer zone which usually surrounds or adjoins the core area is for cooperative activities compatible with sound ecological practices, including environmental education, recreation, ecotourism and applied and basic research. The transition area is a flexible area of cooperation "which may contain a variety of agricultural activities, settlements and other uses and in which local committees, management agencies, scientists, non governmental organisations, economic interests and other stakeholders work together to manage and sustainably develop the area's resources"'.

The national MAB reserves have been selected from the different bio-climatic zones and range from 3 to 50,000 ha, though there are few areas below 10 ha and only two reserves over 10,000 ha (Table 1 ). The different types of climax vegetation such as the tropical wet evergreen forests, dry mixed evergreen forests, patanas and savannah woodlands are represented in the areas designated as reserves.

NARESA provided funds to the Forest Department for demarcating and fencing the MAB reserves, which originated as IBP arboreta, under its programme on demarcation and maintenance of MAB reserves. In 1988, Sinharaja, the largest tract of rainforest remaining in the country, was declared a national heritage wilderness area under the National Heritage Wilderness Areas Act No. 3 of 1988. The recommendation of the MAB National Committee a few years previously to include the Sinharaja forest reserve in the list of World Heritage properties also bore fruit in the same year when it was designated a world heritage site under the UNESCO World Heritage Convention. 
Table 1. Distribution of MAB Reserves - number and extent

\begin{tabular}{|c|c|c|c|c|c|c|c|c|c|c|}
\hline \multirow[t]{2}{*}{ Size category } & \multicolumn{10}{|c|}{ Bio-climatic zone } \\
\hline & \multicolumn{2}{|c|}{$\begin{array}{l}\text { LMWZ } \\
\text { No. Ext. (ha) }\end{array}$} & \multicolumn{2}{|c|}{$\begin{array}{l}\text { DZ } \\
\text { No. Ext.(ha) }\end{array}$} & \multicolumn{2}{|c|}{$\begin{array}{l}\text { LMIZ } \\
\text { No. Ext.(ha) }\end{array}$} & \multicolumn{2}{|c|}{$\begin{array}{l}\text { MWZ } \\
\text { No. Ext.(ha) }\end{array}$} & \multicolumn{2}{|c|}{$\begin{array}{l}\text { All zones } \\
\text { No.Ext.(ha) }\end{array}$} \\
\hline Up to 10 ha & 1 & 3 & 1 & 10 & 1 & 10 & 1 & 6 & 4. & 29 \\
\hline $11-100 \mathrm{ha}$ & 12 & 280 & 3 & 107 & 3 & 53 & 3 & 60 & 21 & 500 \\
\hline $101-1000$ ha & 1 & 102 & 3 & 1959 & 4 & 1139 & 2 & 1213 & 10 & 4413 \\
\hline $1001-10000 \mathrm{ha}$ & 1 & 1619 & 2 & 3035 & 1 & 1344 & 0 & 0 & 4 & 5998 \\
\hline$>10000$ ha & 1 & 11330 & 1 & 50490 & 0 & 0 & 0 & 0 & 2 & 61820 \\
\hline Total & 16 & 13334 & 10 & 55601 & 9 & 2546 & 6 & 1279 & 41 & 72760 \\
\hline
\end{tabular}

LMWZ $=$ Low \& mid country Wet Zone

$\mathrm{LMIZ}=$ Low \& mid country Intermediate Zone
$\mathrm{DZ}=$ Dry Zone

$\mathrm{MWZ}=$ Montane Wet Zone

Source: Compiled from Forest Department data

According to the biosphere reserve concept of the UNESCO MAB programme, each biosphere reserve is intended to fulfil three complementary functions viz, a conservation function, to preserve genetic resources, species, ecosystems and landscapes ; a development function, to foster sustainable economic and human development; and a logistic support function, to support demonstration projects, environmental education and training, and research and monitoring related to local, national and global issues of conservation and sustainable development.

Significant progress has been achieved in the latter function in the Sinharaja biosphere reserve, largely due to the interest and initiative of a research group from the University of Peradeniya (vide Annex 1). In 1980 a "research hut" was constructed at Sinharaja with an allocation of Rs 100000/= from NARESA. Without the provision of this basic facility of a field research station in the forest reserve it is doubtful whether such progress could have been achieved. The facility is managed by the Forest Department along with the conservation and educational centres subsequently developed by the Department. The MAB Committee also recommended funding of a field research station at the Hurulu reserve (1985), and made an allocation of $R_{s} 100,000 /=$ in 1990 towards establishing a facility for researchers at Horton Plains Strict Natural Reserve. However work at Hurulu was stayed due to security reasons, and no progress has been made by the Wild Life Department on the provision of a research facility at Horton Plains as envisaged.

The MAB reserves have no special legal status, but have been administratively designated as $\mathrm{MAB}$ reserves under the existing legislation in Sri Lanka. The 
designation and demarcation of these reserves gave the lead to the establishment of a protected area network in the country, at a time when conservation was not given any priority status in forest management, the main objective of management being timber production. At present however, 33 additional forests covering an extent of 75752 ha have been designated conservation forests by the Forest Department (Table 2 ), based on the results of the National Conservation Review.

Table 2: Extent of protected areas administered by the Forest Department

\begin{tabular}{lcc}
\hline \multicolumn{1}{c}{ Description - Name } & No. & Area (ha) \\
\hline $\begin{array}{l}\text { International biosphere reserves } \\
\text { - Hurulu Forest Reserve }\end{array}$ & 1 & 512 \\
- Sinharaja Forest Reserve/Proposed Reserve & 1 & 8,864 \\
$\quad$ National biosphere reserves & 39 & 63,384 \\
\hline Conservation forests (wet zone) & & \\
- Knuckles Conservation Forest & 1 & 16,000 \\
- Sinharaja National Heritage Wilderness Area & 1 & 11,187 \\
- Other conservation forests & 31 & 60,525 \\
\hline Total & 74 & 160,472 \\
\hline Total - corrected ${ }^{1}$ & $\mathbf{7 2}$ & $\mathbf{1 4 8 , 5 1 2}$ \\
\hline
\end{tabular}

${ }^{1}$ Corrected for seven national biosphere reserves (Diyadawa, Gilimale-Eratne, Haycock, Kanneliya, Kombala-Kottawa, Oliyagankele and Rammalakanda), with a total area of 1,477 ha, which are located within wet zone conservation forests, Dotalugala national biosphere reserve (1,619 ha) in the Knuckles Conservation Forest and Sinharaja Biosphere Reserve which lies within Sinharaja National Heritage Wilderness Area.

Source : IUCN, WCMC \& FAO (1997).

The national system of protected areas covers over $14 \%$ of total land area, the area managed by the Forest Department and the Wild Life Department being $2.2 \%$ and $12.4 \%$ respectively. This is higher than in many other South and South-East Asian countries. However many of the protected areas are small and isolated reflecting the fragmented nature of much of the remaining natural habitat. Sixty one percent of the MAB reserves are less than 100 ha in extent and $85 \%$ less than 1000 ha (Figure 1). The situation with the protected areas administered by the Wild Life Department is somewhat better with most of the areas being over 1000 ha. Nevertheless opportunities to protect large blocks of forest are becoming fewer. 


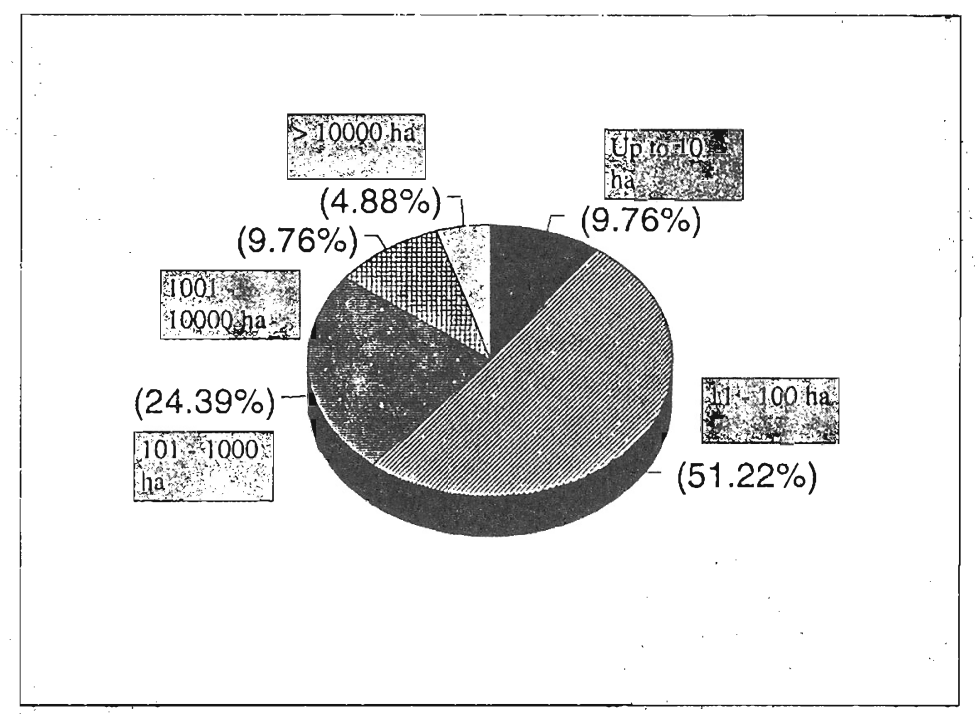

Figure 1: Distribution of $\mathrm{MAB}$ reserves by size

There is a need to review and rationalise the national MAB reserves in the context of the total protected area network in the country. Boundaries of the reserves have been demarcated several years ago, and the present extents in many areas may have to be revised according to the ground situation. In cases where the MAB reserve falls within an area declared a conservation forest, this will form the core area within a larger, protected area. This exercise will have to be done by the Forest Department in the context of the recently concluded National Conservation Review, whose over-riding objective was to define a national system of conservation forests in which watersheds important for soil conservation and hydrology are protected, forest biodiversity is fully represented and cultural, economic and social needs are met.

The sites designated as MAB reserves in Sri Lanka are all forest areas. Other ecosystems are not represented. This deficiency is not only in the case of Sri Lanka's MAB reserves. An international conference of experts was organised by UNESCO in 1995 in Seville, Spain, at which a strategy, now known as the "Seville Strategy", with recommendations for the future development of biosphere reserves in the 21st century were drawn up. Under one of the ten key directions identified by the conference which laid the foundation for the strategy, it is noted that "there is a particular potential, and need, to apply the biosphere reserve concept in the coastal and marine environments". The MAB National Committee is presently looking into suitable wetland or coastal areas for designation as reserves. 


\subsection{RESEARCH}

The MAB Committee initiated and sponsored a number of studies particularly during the early years, during which time the broad area of natural resources and environment came under its purview. NARESA provided initial financing: of Rs 89100/- in 1971 for 6 projects, and from 1977 onwards a special allocation for MAB activities was provided -

$\begin{array}{ll}1977- & 300,000 /- \\ 1978- & 400,000 /- \\ 1979- & 480,000 /-\end{array}$

The Mahaweli Development Board contributed a sum of Rs.730,000/= in 1979, and a further Rs. 100,000/= the following year, for the project in the Mahaweli area. Some studies were funded by UNESCO.

The projects undertaken by the MAB Committee are listed at Annex 2. One of the first and most significant studies initiated by the Committee viz, monitoring of the environmental impact of the Mahaweli project is described below.

\subsection{Monitoring of the total environmental impact of the Mahaweli project}

The Accelerated Mahaweli Irrigation Project as envisaged at the time (late 1970s) was the largest development project ever undertaken in Sri Lanka. The trans-basin water diversion, creation of new reservoirs, clearing of forests, land development, settling of farmers' families, intensive agriculture and other activities would cause drastic and often permanent changes to the natural ecosystem. Based on a pre-feasibility report prepared by NARESA in 1977, the MAB National Committee embarked on three sub-projects in an attempt to study the total environmental impact of the project:

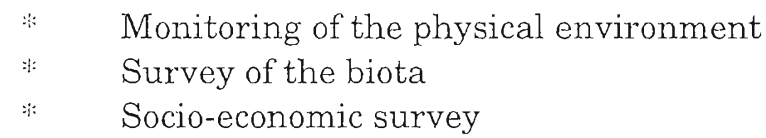

\section{Monitoring of the physical environment}

The following projects were carried out:

(a) Water - the chemical balance of the irrigation system of theKalawewa area was studied for the purpose of predicting thequality of irrigation and drainage waters. A number of chemical and physicalparameters were analysed.

(b) Soil - this project was carried out with the objective of monitoring the changes in the soils of System H of the Mahaweli Project resulting from the introduction of irrigation and intensive cultivation. 
(c) Climate \& hydrology - The purpose of this study was to monitor and evaluate the impact of development on the climate, soil and hydrology of Kalawewa.

\section{Monitoring of the biotic environment}

\footnotetext{
Flora - A study of the flora of the System $\mathrm{H}$ area was designed to be carried out over a period of time so that changes could be monitored and compared with baseline data obtained fiom relatively undisturbed areas.

Fauna - The primary objective of this study was to gather baseline data on the composition and distrubution of important parts of the aquatic fauna, particularly the plankton, major benthic forms and major fish forms.
}

\section{Socio-economic survey}

The objective of this study was to obtain socio-economic data from the settlers. An area where farmers were already resident, and a village which would not be directly influenced by the Mahaweli project, were also included in the survey.

The entire project was carried out with the collaboration ancl support, including financial support, of the Mahaweli Development Board and the findings were communicated to the Board in confidential briefings and reports. This was mainly because some of the results could be wrongly interpreted and possibly cause embarassment to the authorities. However the work has been published in several scientific papers and two M.Phil theses.

The scenario at the time the work was started by NARESA and the MAB National Committee was: there was considerable pressure on the natural resources and environment of the country as a result of the rapidly growing population, and a general lack of official recognition of the importance of environmental protection, in the absence of legislation specifically for environmental protection and management. The National Environmental Act was enacted in 1980 and amended subsequently; the Environmental Impact Assessment process came into effect years later. Thus, this is a major contribution of the MAB National Committee to environmental conservation and national development quite apart from the scientific output and research training benefits from the studies.

\subsection{EDUCATION AND TRAINING IN ENVIRONMENTAL STUDIES}

Sri Lanka was probably one of the best botanized tropical islands by the turn of this century, having attracted many famous foreign scientists to study her rich. and interesting flora (and fauna). Most of the publications were however in 
journals abroad and often in continental European languages and thus inaccessible to researchers in Sri Lanka. Further, the dearth, and in some cases the total inadequacy, of guides or handbooks to the flora and fauna of the country posed a serious constraint for biological field studies in the country. It was to fulfil this need that the MAB Committee sponsored a project for the preparation of checklists and handbooks to the fauna and flora with the objective of preparing background literature on the local plants and animals. The project commenced in 1977 and was centred in the botany and zoology laboratories of the University of Colombo. Under this project, specimens were collected, studied and collated, and check lists of species, keys to and descriptions of genera, and handbooks for their identification prepared. Nearly 10 years later, the MAB Committee initiated the Botanical Survey Project, in order to prepare checklists of plants of selected habitats e. g. salt marsh plants, seashore plants, mangroves and water plants. A total of 21 publications have been produced (Annex 3). This series of checklists and handbooks cover most plant groups, except the lichens and marine algae.

With regard to the fauna, checklists/handbooks have been prepared on birds, mosquitoes, amphibia, mammals and land snails of Sri Lanka. The recently revived Zoological Survey of Sri Lanka, coordinated by NARESA, could now consider filling in the gaps in faunal checklists.

\subsection{REVISION OF THE "FLORA OF CEYLON"}

The MAB National Committee through NARESA was instrumental in reviving the revision of Trimen's Handbook to the Flora of Ceylon, securing funding for the project and coordinating the project. The history of this project warrants record in a review of this nature.

Trimen's Handbook to the Flora of Ceylon, published about a hundred years ago between 1893 and 1900, was considered at that time to be one of the most complete and outstanding works on the flowering plants of any tropical country. In 1931, A.H.G. Alston added to the five volumes of 'Trimen's lilora a sixth containing additions, revisions and corrections. With the passage of time, copies in a satisfactory state of preservation became extremely rare. Further, much new information had accumulated by the middle of this century, and in the light of changing concepts regarding the names and identity of plants, systems of classifications etc. Trimen's handbook proved to be outdated.

Professor B.A.Abeywickrama, recognized the need for an up-to-date Flora, and resolved upon a complete revision or at least its reprinting. In 1967 the Smithsonian Institution initiated a number of research projects in Sri Lanka. Among them were several dealing with plant ecology, in which Professor Abeywickrama was associated as Co-Principal Investigator with Dr F.R. Fosberg of the Smithsonian Institution who was Principal Investigator. In the course of 
their discussions, Professor Abeywickrama suggested that the Smithsonian Institution should initiate a project to revise Trimen's flora. This was taken up and the Flora Revision Project started in February 1968, thirty years ago. The participation of botanists from several countries, most of them experts in particular families represented in the Sri Lankan flora, were enlisted for the study.

The Smithsonian - supported project was originally for five years, and was later extended in stages, and work went on uninterrupted up to December 1979. Arrangements for printing the volumes of the revised flora were made with a publisher in India, before the project came to an end. The first volume of the Revised Flora appeared in 1980, and since then further volumes were published at regular intervals. Dr Fosberg continued to help by editing the manuscripts even after the project came to an end, until his death in 1993. He was one of the founders of the Flora Revision Project, and the success of its first phase was almost entirely due to his efforts.

At the end of the Smithsonian - supported project, of the total of 215 families of Sri Lankan flowering plants, 70 still remained to be revised, and neither the funds for their revision nor the required expertise was available in Sri Lanka. In 1990, acting on a proposal by Professor Abeywickrama, supported by the MAB National Committee, NARESA made a request to the British Overseas Development Administration (ODA) to support the completion of the flora revision. ODA agreed, and appointed the Royal Botanic Gardens, Kew, as their agent. Dr. W.D. Clayton as Principal Investigator enlisted collaborating scientists and co-ordinated their work. NARESA co-ordinated the work in Sri Lanka in collaboration with the Royal Botanic Gardens, Peradeniya, and the Forestry Planning Unit of the Ministry of Forestry through which the funds were channelled as part of a larger project on Forestry Research and Information which commenced in 1991. Prof. M.D. Dassanayake, as Co-Principal Investigator assigned families to the local botanists, and the project was guided by a NARESAAdvisory Committee. The project was based at the National Herbarium. Volumes VII to XI of the Revised Flora were published during this period. The Xth volume, being the furst entirely under ODA auspices, was published in 1996.

By the end of this phase of the project in May 1997, all the flowering plant families of the Sri Lankan flora had been revised, and 11 volumes of the Revised Flora published. The printing of the remaining volumes is expected to end with volume XIV. ODA agreed to support the revision also of the Sri luankan ferns. The work is now in progress, and when the manuscripts are ready a 15th volume will be added to the Revised Flora. NARESA has provided funding for the final phase of this work which is planned for completion by the end of 1998 . A total of 215 families comprising 3662 species are covered in the revision. 
A very significant function of the Flora Project was to give Sri Lankan botanists, especially students, the opportunity to acquire a competence in taxonomic studies by actually working with experts, both in the field as well as in the herbarium. They had the invaluable experience of assisting and working with some of the most outstanding plant taxonomists of our time. The trained men are now pursuing useful careers in taxonomy or related fields in Sri Lanka and. other countries.

In the course of their herbarium work, the scientists rendered to the National Herbarium in Peradeniya the most valuable service of annotating the specimens with their correct, up-to-date names, which greatly increased the value and usefulness of the specimens to other users of the herbarium. The project added to the National Herbarium about 50,000 new specimens of Sri Lankan plants collected in the course of the work, raising the total collection at the Herbarium from about 75,000 to about 125,000 .

The field work involved in the revision of the flora helped to draw attention to the wealth and diversity of Sri Lanka's plant resources and also to the degradation of the natural vegetation and the resulting disappearance or increasing variety of some species. Some species that Trimen reported as common in his day are now rare ; some have been located only after much search or have not been located at all.

The volumes of the revised flora have provided ecologists, students of wild life and conservationists with new information regarding the identity of Sri Lankan plant species, and their distribution within the country and in neighbouring countries. In addition, botanists participating in the revision have published scientific papers in local and international journals with descriptions of rare and new species.

The completion of the flora revision is not in any sense the end of floristic study in Sri Lanka. As Trimen has said in the introduction to his book, the study of a country's plant life is a continually advancing and never ending process. In fact, in the light of knowledge that has accumulated in recent years, many parts of the earlier revised volumes are already in need of revision. The flora revision brought together existing information gained from the taxonomic study of our flowering plants to form an up-to-date knowledge base. It now remains to further investigate groups, large or small, in greater detail and so build on this base and advance our know].edge of our plant life and plant resources.

Trimen's Flora and the revision deal only with the flowering plants of Sri Lanka, apart from the ferns which are being revised now. Groups such as the liverworts and mosses, fungi, algae and lichens, have never been studied to the same depth as the flowering plants. Among them may be species which will one day prove to be very valuable natural resources. It is hoped that means will be 
found to survey these groups as well, and so produce a complete information base of the plant resources of our country. To carry on this work what is needed is an ongoing Botanical Survey with permanent staff and annual budgetary allocations, like the Botanical Survey of India. A recommendation to this effect has been made to the Director General of the Deparment of Agriculture under whom the National Herbarium functions.

\subsection{OTHER ACTIVITIES}

The MAB National Committee has sponsored and organised several workshops and seminars. Three regional meetings are worthy of mention :

(a) Regional training workshop on the Ecology and Conservation of Humid Tropical Forests of the Indo-Malayan Realm held in Colombo in 1987 with technical and financial assistance from UNESCO, World Heritage Convention and USAID. Participants from 11 countries in the South and South East Asian region including Sri Lanka attended the workshop.

(b) International symposium on the Ecology and Landscape Management in Sri Lanka, held in Colombo in 1990. Over 200 scientists, both local and foreign, attended the symposium which was co-sponsored by NARESA.

(c) Regional seminar on the Forests of the Humid Tropics of South and South East Asia held in Kandy, in 1996 to commemorate 40 years of the study of tropical vegetation under the umbrella of UNESCO. This was jointly funded by UNESCO, NORAD and the MacArthur Foundation. Sixty local and foreign scientists attended, and 28 papers were presented. The proceedings of this seminar are in press.

Environment education programmes have also been undertaken. In a NARESA-March for Conservation (MfC) joint programme on promoting and enhancing conservation education in Sri Lanka, the following were carried out commencing 1992 : preparation and publication of educational and publicity posters on coral reefs; production of simple pictorial booklets for young students on mammals, birds, rainforests etc; workshops for teachers to enhance their skills with respect to conservation education. This programme was a sequel to the NARESA-MfC programme carried out earlier to identify the constraints to making conservation education in schools meaningful and effective.

The MAB National Committee functioning as a watch-dog organisation on the environment took part in the discussion of the environmental impacts of the proposed Forestry Master Plan (1986) and alerted the authorities on the problems inherent in the proposed plan. This intervention contributed in no small measure to the eventual revision of the plan. Recommendations have also been made to the authorities on various aspects such as conservation measures to be implemented with regard to endangered species (1985), land alienation (1990), export of water plants and ornamental fish (1993), and landslides (1994). 


\subsection{FUTURE DIRECTIONS}

The preservation of genetic resources, species, ecosystems and landscapes is a key function of biosphere reserves. The MAB National Committee has planned to get a review of the biosphere reserves with regard to their integrity and status, and their place in the protected area network in the country. Selection of new areas e.g. Knuckles, Peak Wilderness, and a wetland or coastal habitat for designation as MAB reserves will be considered.

But biosphere reserves are much more than just protected areas. They promote an integrated approach to achieving a sustainable balance between the sometimes conflicting goals of conserving biodiversity, promoting economic development and maintaining associated cultural values. They are thus well placed to contribute to the implementation of the International Convention on Biological Diversity whose major objectives are the conservation and sustainable use of biodiversity, and equitable sharing of the benefits arising from its use. Perhaps more attention needs to be given to the development function in the national reserves in general. As stated earlier, much has been achieved in promoting research \& monitoring, education \& training and demonstration projects in Sinharaja. Attention should now be focussed on developing the logistic support function in other reserves as well.

The Seville Strategy ${ }^{1}$ provides recommendations for developing effective biosphere reserves and for setting out the conditions for the appropriate functioning of the World Network of Biosphere Reserves. It suggests the level i.e. international, national, and individual biosphere reserve, at which each recommendation will be most effective. Monitoring the implementation of these recommendations will be an important part of the MAB programme.

Sponsoring of research is an ongoing activity under the MAB programme. Research on the biosphere is carried out under NARESA's committees such as the Biological Sciences Committee and Natural Resources Committee, and the Zoological Survey of Sri Lanka. The MAB committee is currently considering a research project on population dynamics of selected endemic fish species.

Biodiversity information is central to any effort towards better conservation and management of living resources. The MAB committee has embarked on a programme to retrieve as much as possible of the available unpublished data on Sri Lanka's biodiversity and publish selected information as a series of MAB Occasional Papers.

It is expected that the MAB National Committee will continue to be alert to important environmental issues facing the country from time to time, be it deforestation, export of threatened plants and animals, bio-piracy, import of 
Genetically modified organisms etc., and make recommendations to the authorities, through NARESA, for better conservation and management of our natural resources and environment.

\section{Acknowledgement}

The author thanks Prof. B.A. Abeywickrama for helpful discussions, and Prof. M.D. Dassanayake for his written contribution on the Revision of the Flora.

\section{References}

[Information has been gleaned from NARESA Annual Reports and files in addition to the references listed here]

Cited :

1. UNESCO. (1996). Biosphere reserves : the Seville Strategy and the statutory framework of the World Network. UNESCO, Paris.

Others :

2. Abeywickrama, B.A. (1982). The MAB programme in Sri Lanka. Vidurava 6(2) : 1-2.

3. Abeywickrama, B.A. (1982). MAB studies in Sri Lanka. Vidurava $6(2): 5$.

4. FPU (1995). Sri Lanka Forestry Sector Master Plan. Ministry of Agriculture, Lands \& Forestry. 511 pp.

5. IUCN, WCMC and FAO (1997). Designing an optimum protected areas system for Sri Lanka's natural forests. Volume 1. A report prepared for the Forest Department. 202 pp.

6. Ministry of Environmental \& Parliamentary Affairs (1991). Sri Lanka National Report to the United Nations Conference on Environment and Development. $170 \mathrm{pp}$.

7. Pushparajah M. (1982). Man and biosphere reserves. Vidurava 6(2): 3-4.

8. UNESCO Man and the Biosphere National Committee for Sri Lanka. (1980). Mahaweli Environmental Studies Progress Report No. 1. 56 pp (unpublished). 
Annex 1

\section{USE OF THE SINHARAJA BIOSPHERE RESERVE FOR RESEARCH, MONITORING, EDUCATION AND TRAINING*}

The Sinharaja World Heritage site was used at the first instance to describe the floristic diversity of woody plant species and identification of threatened as well as economically important species, ${ }^{1.2 .3}$ population biology, reproductive biology and regeneration dynamics of economic plants with a view to their domestication. ${ }^{4.5}$ They were followed by interdisciplinary studies including applied ecological-forestry and seedling ecology $y^{6,7.8,9}$, sociological and resource economics ${ }^{10,11,12}$; comparative studies on soil biology and fertility and nutrient dynamics of natural and modified forests including monoculture plantations. These studies yielded useful baseline information on soil fertility in relation to land use in the rain forest and the buffer zone. ${ }^{13,1,1,15,1,16}$ Studies on reproductive biology, genetic diversity, mating systems $s^{\overline{5} .17 .1 \mathrm{~s}}$ and molecular cladistics ${ }^{19}$ provided valuable information on genetic diversity within and among populations, genetic relatedness among sympatric clades of species and information for plant breeding and improvement. Restoration of late-successional rain forest canopy species using Pinus caribaea as a nurse species in Sinharaja ${ }^{7.20,21}$ have yielded extremely useful results for forestry extension work in the buffer zone through local participation. These interdisciplinary and inter-institutiona] collaborative research efforts have paid rich dividends in guiding research along the $\mathrm{MAB}$ concepts.

All the above studies strengthened national, regional and international collaboration in research, education and training. They provided the opportunity for: post-graduate researchers from local and overseas institutions to participate in research at Sinharaja. The active participation of overseas collaborator's in research and education has contributed significantly to the improvement of research and teaching in forest ecology and management at Peradeniya University. Furthermore, in all the studies, the local villagers were given an opportunity to participate, thus making this research more meaningful to them and at the same time harnessing their indigenous knowledge of the forest. Some of these field assistants are working now as visitor guides thereby sharing their experience with the visitors.

The scientists have collaborated with international research networks like the Tropical Soil Biology and Fertility (TSBF) programme, International Working Group on Dipterocarpaceae (IWGD), International Network for DIVERSITAS in Western Pacific and Asia (DIWPA) and Center for Tropical Forest Science (CTFS) Smithsonian Tropical Research Institute (STRI). This collaboration allowed them to participate in ecological and environmental monitoring and modelling at national, regional and global level. The adoption of standardized protocols for data collection and management in these networ.k studies facilitated the accessibility, interchange and utilization of scientific information

Abstracted from a submission to NARESA by Drs C.V.S. \& I.A.U.N. Gunatilleke and Drs P.S. \& P.M.S. Ashton - July 1997 
generated on the floristic composition and dynamics in rain forest ecosystems.

These research findings have been incorporated into undergraduate as well as school curricula and field training programmes, school exhibitions, poster sessions, visitor guides and national level biodiversity action plans, forestry and forest research policy guidelines. A field guide to the common tree and shrub species of Sri Lanka was published recently ${ }^{22}$ with the experience gained over the years on the Sri Lankan flora.

The research group has over the decades created a truly international collaborative research programme focused on the sustainable management and conservation of rain forests in Sri Lanka. The strength of this programme has been based on the initial biological studies going on for over 20 years in the Sinharaja forest. This programme is now fully complemented by researchers involved with social and economic analyses of resource use issues in the south-west of Sri Lanka. The close collaboration of the research group with the Forestry Planning Unit and the Forest Department under the Ministry of Forests and Environment has paved the way for incorporating the research outputs into national level forestry planning and implementation in Sri Lanka.

\section{References}

1. Gunatilleke C.V.S. \& Gunatilleke I.A.U.N. (1983). A forestry case study of the Sinharaja rain forest in Sri Lanka. In: Forest and watershed development and conservation in Asia and the Pacific (Ed. L. Hamilton). Westview Press, Colorado, 289-358.

2. Gunatilleke C.V. S. \& Gunatilleke I.A.U.N. (1985). Phytosociology of Sinharaja : a contribution to rain forest conservation in Sri Lanka. Biological Conservation $31: 21-40$.

3. Gunatilleke I.A.U.N. \& Gunatillek C.V.S. ( 1993). Underutilized food and medicinal plant resources of Sinharaja rain forest in Sri Lanka. In: Food and nutrition in the tropical rain forest: biocultural interactions. ( Eds. C.M. Hladik, A. Hladik, H. Pagazy, O.F. Linares \& M. Hadley ) Man and the Biosphere Series, Vol. 15 UNESCO, Paris \& Parthenon Publishing Co., Carnforth, UK.

4. de Zoysa N.D. Gunatilleke, C.V.S. \& Gunatilleke I.A.U.N. (1990). Comparative phytosociology of natural and modified rain forest sites in Sinharaja MAB reserve in Sri Lanka. In: Rain forest regeneration and management (Eds. A. Gómez-Pompa, T.C. Whitmore \& M. Hadley). Man \& the Biosphere Series 6:215-223, Parthenon Publishing Group, Carnforth, UK \& UNESCO, Paris. 
5. Dayanandan S., Attygalle D.N.C., Abeygunasekera A.W.W.L., Gunatilleke I.A.U.N. \& Gunatilleke C.V.S. (1990). Phenology and floral morphology in relation to pollination of some Sri Lankan Dipterocarps. In: Reproductive ecology of tropical forest plants [Eds. K.S. Bawa \& M. Hadley] Man \& Biosphere Series 7: 105-135. UNESCO \& Parthenon Publishing, UK.

6. Ashton P.M.S., Gunatilleke C.V.S. \& Gunatilleke I.A.U.N. (1995). Seedling survival and growth of four Shorea species in a Sri Lankan rain forest. Journal of Tropical Ecology 11: 263-279.

7. Ashton P.M.S., Gamage S., Gunatilleke I.A.U.N. \& Gunatilleke C.V.S. (1997). Restoration of a Sri Lankan rain forest: using Caribbean pine (Pinus caribaea) as a nurse for establishing late-successional tree species. Journal of Applied Ecology. 34.

8. Gunatilleke I.A.U.N., Ashton P.M.S., Gunatilleke C.V.S. \& Ashton P.S. (1996). An overview of seedling ecology of Shorea (section Doona) Dipterocarpaceae. In: Biodiversity and the dynamics of ecosystems (Eds. I.M. Turner, C.H. Diong, S.S.L. Lim \& P.K.L. Ng). International Network of DIVERSITAS in Western Pacific and Asia. 81-102.

9. Gunatilleke C.V.S., Perera G.A.D., Ashton P.M.S., Ashton P.S. \& Gunatilleke I.A.U.N. (1996). Seedling growth of Shorea section Doona (Dipterocarpaceae) in soils from topographically different sites of Sinharaja rain forest in Sri Lanka. In: Ecology of tropical forest seedlings (Ed. M.D. Swaine), Parthenon Publishing, Carnforth, U.K.

10. Abeygunawardane P. (1993). Total economic value of forests: the case of Sinharaja Forest in Sri Lanka. Paper presented at the World Bank sponsored regional seminar in Kandy. October, 1993.

11. McDermott M., Gunatilleke C.V.S. \& Gunatilleke I.A.U.N. (1990). The Sinharaja rain forest: conserving both biological diversity and a way of life. The Sri Lanka Forester 19 (3\&4) New Series 3-22.

12. Caron C. (1994). Securing and conserving: food, property and the Sinharaja forest. Unpublished M.Sc. project report, Yale School of Forestry and Environmental Studies, USA.

13. Maheswaran, J. \& Gunatilleke, I.A.U.N. (1988). Litter decomposition in a lowland rain forest and a deforested area in Sri Lanka. Biotropica 20(2):90-99.

14. Hafeel K.M. \& Gunatilleke I.A.U.N. (1989). Distribution of endomycorrhizal spores in disturbed sites of a lowland rain forest in Sri Lanka. In: Mycorrhizae for Green Asia (Eds. A. Mahadevan, N. Raman \& K. Nadarajan), University of Madras, Madras. 37-45. 
15. Myres R.J.K., Palm C.A., Cuevas E., Gunatilleke I.A.U.N. \& Brossard M. (1994). The synchronisation of nutrient mineralisation and plant nutrient demand. In:The Biological management of tropical soil fertility ( Eds. P.L. Woomer \& M.J. Swift) John Wiley and Sons, New York. 81-116.

16. Cohen A.L., Singhakumara B.M.P. \& Ashton P.M.S. (1995). Releasing rain forest succession: a case study in the Dicranopteris linearis fernlands of Sri Lanka. Restoration Ecology 3(4): 261-270.

17. Murawski D. A., Dayanandan B. \& Bawa K.S. (1994). Outcrossing rates of two endemic Shorea species from Sri Lankan tropical rain forests. Biotropica 26(1): 23-29.

18. Murawski D.A., Gunatilleke, I.A.U.N. \& Bawa K. S. (1994). The effects of selective logging on inbreeding in Shorea megistophylla (Dipterocarpaceae) from Sri Lanka. Conservation Biology 8 : 997-1002.

19. Dayanandan S. (1996). Phylogeny of the tropical tree family Dipterocarpaceae based on nucleotide sequences of the chloroplast rbcl. gene and morphology. Ph.D. thesis submitted to Boston University, USA.

20. Ashton P.M.S., Gunatilleke C.V.S. \& Gunatillek, I.A.U.N. (1990). A case for the evaluation and development of mixed species even-aged plan tations in Sri Lanka's lowland wet zone. In: Ecology and landscape management in Sri Lanka. Proceedings of the International and Interdisciplinary Symposium on Sri Lanka (Eds. W. Erdelan, C. Preu, N. Ishwaran, \& C.M. Maddumabandara) Margraf Verlag. pp. 275288.

21. Ashton P.M.S., Gunatilleke C.V.S. \& Gunatilleke I.A.U.N. (1990). Ashelterwood method of regeneration for self-sustained timber production in Mesua-Shorea forest of south-west Sri Lanka. In: Ecology and landscape management in Sri Lanka. Proceedings of the International and Inter disciplinary Symposium on Sri Lanka. (Eds. W.Erdelan, C. Preu, N. Ishwaran, \& C.M. Maddumabandara) Margraf Verlag. pp. 255-273.

22. Ashton M.S., Gunatilleke S., de Zoysa N., Dassanayake M.D., Gunatilleke N. \& Wijesundera S. (1997). A field guide to the common trees and shrubs of Sri Lanka. WHT Publications (Pvt.) Ltd. Colombo.431 pp. 
Annex 2

\section{PROJECTS OF THE MAB NATIONAL COMMITTEE}

1. Education \& training in environmental studies - Preparation of check lists of fauna and flora of Sri Lanka

2. Study of the problems associated with nutrition and development of mycorrhiza in pine plantations

3. Pollution studies in the Kelani river

4. Demarcation and maintenance of MAB reserves (started as IBP arboreta)

5. Geographical and ecological distribution of the endemic species in Sri Lanka

6. Grassland study project/Grassland ecosystems

7. Study of ectotropic mycorrhizas in forest plants

8. Surveying levels of pesticides in food

9. Monitoring the water quality in Colombo and its environs

10. Sinharaja forest studies - microbiological studies

11. Mahaweli project

(a) Socio-economic studies

(b) Monitoring of the biotic environment - fauna \& flora

(c) Monitoring of the physical environment - water, soil and climate \& hydrology

12. Pesticide and water quality monitoring programme for system $B$ of the Mahaweli project

13. The ecology and social biology of the western people faced leaf monkey

14. Integrated land use and utilisation of resources in Mahawewa/Pannala micro-catchment

15. Demographic studies of some Dipterocarp species in the Sinharaja Forest

16. Preparation and compilation of a floristic inventory of the Sinharaja Forest

17. Conservation of indigenous medicinal plants WWF Project 3320

18. Study of the phenology and the relative growth rates of certain selected mangrove species in Southern Sri Lanka (RG/MAN/93/01)

19. Effects of industrialization and urbanization on mangroves with reference to river water pollution and upstream land uses (RG/MAN/93/02)

20. To assess the quantity of live plants and animals, and preserved plants and animals, or parts thereof exported (RG/93/MAB/01)

21. Identifying and processing botanical specimens from the Sinharaja forest (RG/97/MAB/01) 


\section{MAB PUBLICATIONS}

\section{Checklists and Handbooks}

1. A Checklist of the liverworts of Sri Lanka (1978). B A Abeywickrama \& M A B Jansen.

2. A Checklist of the mosses of Sri Lanka (1978). B A Abeywickrama \& M A B Jansen.

3. A Checklist of the pteridophytes of Sri Lanka (1979). B AAbeywickrama.

4. A Handbook to the fungi parasitic on the plants of Sri Lanka (1979).

U Coomaraswamy.

5. A Handbook to the agarics of Sri Lanka (1979). U Coomaraswamy.

6. A Handbook to the freshwater algae of Sri Lanka (Part I) (1979).

B A Abeywickrama.

7. A Handbook to the soil fungi of Sri Lanka (1981). U Coomaraswamy.

8. A Checklist of mosquitoes of Sri Lanka (1981). N. Jayasekera \& Robert V Chelliah.

9. A Checklist of the mammals of Sri Lanka (1982). K D Arudpragasam, S W Kotagama \& I Kotelawala.

10. A Checklist of amphibia of Sri Lanka (1982). K D Arudpragasam, S W Kotagama \& I Kotelawala.

12. A Handbook to the families of the flowering plants of Sri Lanka (Part I) (1983). B A Abeywickrama.

13. A Checklist of land snails of Sri Lanka (1983). K D Arudpragasam.

14. A Handbook to the fungi associated with insects of Sri Lanka (1983). U Coomaraswamy.

15. The Genera of freshwater algae of Sri Lanka - Part II - Cyanophyceae (1986). B A Abeywickrama.

17. A Handbook to the macrofungi of Sri Lanka (1988). U Coomaraswamy \& S Kumarasingham.

18. The Marine angiosperms of Sri Lanka (1992). B A Abeywickrama \& P Arulgnanam.

19. An illustrated manual of rice-field weeds in Sri Lanka (1992). J P N R Chandrasena.

20. The Coastal plants of Sri Lanka Part I (Salt marsh plants) (1993). B A Abeywickrama \& P Arulgnanam.

21. Checklist of woody perennial plants of Sri Lanka (1994). Yvonne Wijesinghe. NARESA-Forest Department. 


\section{Other Publications}

Bibliography of literature relating to marine turtles of Sri Lanka (1994). Suhashini Hewavishenthi.

Sinharaja World Heritage Site in Sri Lanka (1996). Nimal \& Savithri Gunatilleke.

Common Vegetables of Sri Lanka (1998). Tissa Herath, S. Somaratne \& P. P. D.C. Perera. 